\title{
Analysis of cropping intensity and irrigation intensity in North Twenty Four Parganas district, West Bengal, India
}

\begin{abstract}
An attempt has been made in this paper to analyse the spatio-temporal variations of cropping intensity and irrigation intensity, and their relationship, in North Twenty Four Parganas district in West Bengal, India from $1996 / 97$ to $2015 / 16$. The relationship between cropping intensity and irrigation intensity has been assessed using partial correlation, residual mapping and hierarchical cluster analysis. One-way ANOVA has been conducted for testing the equality of cluster means. Temporal analysis from 1996/97 to $2015 / 16$ has shown a low positive correlation between cropping intensity and irrigation intensity for the entire district. Analysis at Agricultural Block level has revealed that cropping intensity decreased in many cases even after an increase in irrigation intensity. In general, cropping intensity has increased with the increase in irrigation intensity in the Coastal Saline Region and the Ichhamati Basin, whereas cropping intensity has increased even after a decrease in irrigation intensity in the Gangetic Plains Region in the district.
\end{abstract}

Keywords

Cropping intensity - hierarchical cluster analysis • irrigation intensity • ANOVA $•$ residual mapping

(C) University of Warsaw - Faculty of Geography and Regional Studies

Introduction

Cropping intensity and irrigation intensity are two significant indicators for measuring the agricultural development of a region. Cropping intensity essentially determines the nature of crop production and the cropping pattern, the scope for crop diversity and crop rotation, opportunities with regard to farming incomes, and rural employment. The availability of irrigation water and its proper usage largely controls the extent of cropping intensity. Indepth study of cropping intensity and recognizing its patterns are significant tasks for agricultural geographers as the concept of intensity has been used extensively in the literature to explain the spatial organization of agriculture' (Dayal 1978, p. 289). Cropping intensity is considered a significant measure of food security, and net production in a region is largely dependent on it (Jain et al. 2013). Taking initiatives to increase cropping intensity is one of the well-established strategies to enhance farm productivity and rural employment. However, existing agro-ecological conditions and the nature of input utilization in agriculture largely determine the level of cropping intensity. Considering all farm inputs, the availability of irrigation water and its effective use largely control the extent of cropping intensity. Based on the study in Nepal, Kaini, Gardner and Sharma (2020) stated that within an irrigated area, the conversion of subsistence farming into commercial farming enhances cropping intensity. In the analysis of global patterns of cropping intensity, Siebert, Portmann and Döll (2010) observed that low cropping intensity has been found in arid regions without irrigation facilities and high cropping intensity in areas where irrigation water is available. Bhattarai, Sakthivadivel and Hussain (2002) stated that the scope of employment opportunities and the poverty levels in rural areas are influenced by variations in the cropping intensity
Tarun Kumar Mondal $\mathbb{C}$, Santana Sarkar

Department of Geography, University of Kalyani, Kalyani, India e-mail: mondaltarunkly@gmail.com e-mail: sarkarsantana1991@gmail.com

Received: 8 December 2020

Accepted: 11 May 2021

between irrigated and unirrigated regions. They also mentioned that migration from low cropping intensity regions, resulting from rainfed agriculture or poorly developed irrigation systems, to regions with available irrigation water is a common scenario in the rural economies of Asian countries. Dhawan (1988) highlighted the spatio-temporal correspondence between cropping intensity and irrigation ratio (ratio of gross irrigated area to net sown area) in India. He further mentioned that cropping intensity in India rose from $114.7 \%$ to $123.6 \%$ during the period from $1960 / 61$ to $1980 / 81$, whereas the irrigation ratio increased from $16.9 \%$ to $28.6 \%$ in the same period. Similarly, Dhawan and Datta (1992) confirmed that the rise in cropping intensity is closely associated with the expansion of irrigation in all of India. Sharma (2015, p. 13) wrote that in India, 'the rate of increase in total cropped area was higher $(3.53 \%)$ during the 2000 s compared with 1990 s $(2.1 \%)$ mainly due to increase in area under irrigation'. He also stated that cropping intensity in India has increased from $128.9 \%$ to $138 \%$ from the early 1990 s to $2011 / 12$ due to the substantial expansion of the area under irrigation. Narayanamoorthy, Alli and Suresh (2015, p. 334) opined that an 'irrigation facility allows the farmers to use the land more intensively throughout the year with higher level of cropping intensity, which is not possible under un-irrigated land'. They also expressed that 'given the highly inelastic supply of land and reduced net sown area, the future growth of agriculture will have to heavily rely on irrigation facility as it allows for multiple cropping on the same piece of land' (Narayanamoorthy, Alli \& Suresh 2015 , p. 334). Hussain and Hanjra $(2004$, p. 13) stated that 'cropping intensity, crop productivity, labor productivity and employment, and household income are all higher in irrigated than rainfed 

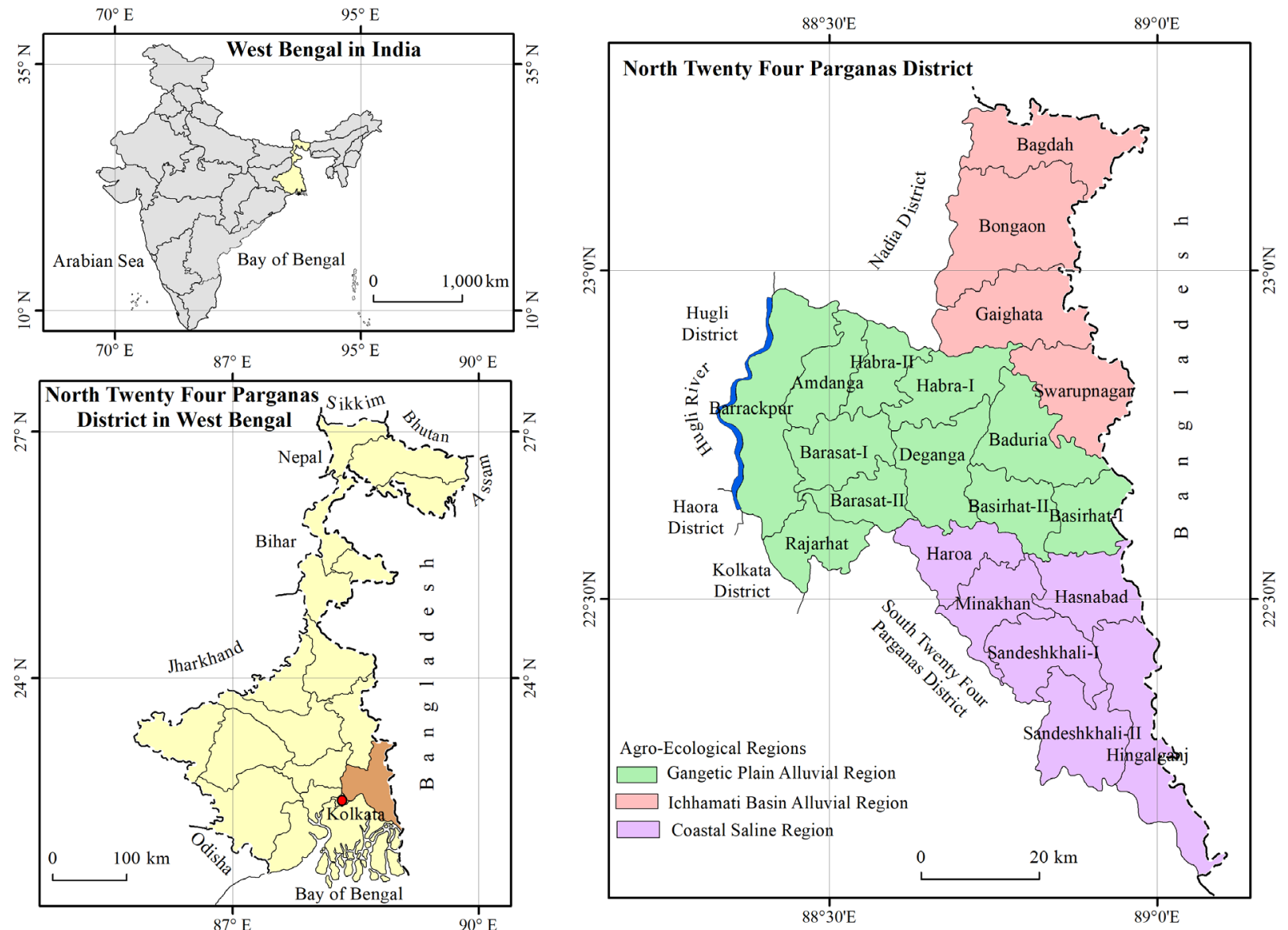

Figure 1. Location map of the study area

Source: Government of India 2011

settings'. According to Biradar and Xiao (2011, p. 368), 'irrigation and multiple-cropping agriculture in India has been a key component of economic development and poverty alleviation'.

The literature available on cropping intensity, irrigation intensity and their spatial correspondence are mainly concentrated at sub-national, national, and global levels. Therefore, an in-depth study on irrigation intensity and cropping intensity, as well as their association at district level, is essential for the design of a location-specific and comprehensive plan for agricultural development. In this context, an attempt has been made in this paper to analyse the spatio-temporal variations of cropping intensity and irrigation intensity, and their relationship, in North Twenty Four Parganas district, West Bengal, India during the $1996 / 97$ to $2015 / 16$ period.

\section{Study area}

North Twenty Four Parganas district extends from $22^{\circ} 08^{\prime} \mathrm{N}$ to $23^{\circ} 16^{\prime} \mathrm{N}$ latitudes and $88^{\circ} 18^{\prime} \mathrm{E}$ to $89^{\circ} 04^{\prime} \mathrm{E}$ longitudes (Fig. 1). The district covers an area of approximately $4,094 \mathrm{~km}^{2}$. Physiographically, the study area is located in the Lower Gangetic Delta region of West Bengal and it shares an international boundary with Bangladesh in the east. The entire study area experiences a hot and humid tropical monsoon climate. As per the 2011 Census report, the total population of the district was recorded as $10,009,781$ persons, of which $42.73 \%$ live rurally (Gol 2011). The participation rate for rural work was reported as $36.43 \%$, and $53.78 \%$ of this population was directly engaged in agriculture (Gol 2011). The rural main work participation rate was recorded as $28.65 \%$ in 2011 , of which $53.53 \%$ were engaged in agriculture (Gol 2011). The rural main work participation rate fluctuated from $28.17 \%$ in 1991 to $27.88 \%$ in 2001 (Gol 1991; Gol 2001). Of the total rural main workers, the agricultural workforce comprised 66.65\% in 1991 and 49.48\% in 2001 (Gol 1991; Gol 2001). The district is divided into 22 Community Development Blocks (CD Blocks) and 21 Agricultural Blocks. Two CD Blocks, namely Barrackpur-I and Barrackpur-II, are jointly known as one Agricultural Block, namely Barrackpur. The boundaries of the remaining $20 \mathrm{CD}$ Blocks are identical to those of the Agricultural Blocks. The conversion of agricultural lands into non-agricultural uses restricts the horizontal expansion of agriculture in this district (DPD, GoWB 2010; Sahana, Ahmed \& Sajjad 2016; Dhali, Chakraborty \& Sahana 2018). The increase in population and the urban expansion, due to it being in close proximity to Kolkata city, accelerate this conversion. The population density in rural areas increased from 980 persons $/ \mathrm{km}^{2}$ in 1991 to 1,277 persons $/ \mathrm{km}^{2}$ in 2011 (Table 3) and urban population increased from $51.23 \%$ to $57.27 \%$ during the same period (Gol 1991; Gol 2011). The continuous influx of undocumented migrants from Bangladesh to North Twenty Four Parganas district also increased population pressure (Gillan 2002; Datta et al. 2008; Ghosh 2011). Moreover, croplands are being converted by fish farming in this district (DPD, GoWB 2010). The study area suffers from problems such as devastating floods, drainage congestion and acute waterlogging. Out of 21 Agricultural Blocks, six of them, namely Hingalganj, Hasnabad, 
Sandeshkhali-I, Sandeshkhali-II, Haroa and Minakhan, are part of the Indian Sundarbans delta, which is exposed to severe cyclones and the intrusion of saline water in agricultural fields (Danda et al. 2011; Sánchez-Triana et al. 2014; Sahana, Ahmed \& Sajjad 2016).

\section{Methodology}

This study is mainly based on secondary data which have been collected from the Office of the Deputy Director of Agriculture, Government of West Bengal, North Twenty Four Parganas district, West Bengal, India and the Office of the Registrar General \& Census Commissioner, Government of India.

Cropping intensity has been calculated following the formula of dividing the gross cropped area by the net cropped area in a given agricultural year (i.e. 1 April to $31 \mathrm{March}$ ) and multiplying by 100 (BAES, DPSPM, GoWB 2015).

Irrigation intensity has been calculated using the formula of dividing the gross irrigated area area by the gross cropped area in a given agricultural year and multiplying by 100 (Reddy \& Reddy 1992).

The temporal trend in the relationship between cropping intensity and irrigation intensity, in the area under high-yielding varieties (HYVs) of cereals and chemical fertilizers at district level, has been examined using partial correlation.

The Ordinary Least Squares (OLS) technique (Helsel \& Hirsch 2002) has been used to examine the spatio-temporal relationship between cropping intensity and irrigation intensity in North Twenty Four Parganas district for the years 1996/97 and 2015/16. Based on residual values, two residual maps (1996/97 and 2015/16) have been drawn to visualize the relationship between cropping intensity and irrigation intensity in the study area.

Hierarchical cluster analysis (Murtagh \& Legendre 2014; Oehl et al. 2003; Ward 1963) has been performed to identify the homogeneity among 21 Agricultural Blocks in the study area in terms of two cluster variables - cropping intensity and irrigation intensity. The Ward method with squared Euclidean distances has been used in the hierarchical cluster analysis (Murtagh \& Legendre 2014; Ward 1963). The Ward method is based on the error sum of squares (ESS) with the following objective function (Ward 1963, p. 237):

$E S S=\sum_{i=1}^{n} x_{i}{ }^{2}-\frac{1}{n}\left(\sum_{i=1}^{n} x_{i}\right)^{2}$

where, $x_{i}$ indicates the score of the ith individual. Squared Euclidean distance (Jobson 1992, p. 487)

$d_{r s}^{2}=\sum_{j=1}^{p}\left(x_{r j}-x_{s j}\right)^{2}$

where,

'the rth and sth rows of the data matrix $\mathrm{X}$ will be denoted by ( $\left.x_{r^{1}}, x_{r^{2}}, \ldots, x_{r} p\right)$ and $\left(x_{s^{1}}, x_{s^{2}}, \ldots, x_{s} p\right)$, respectively. These two rows correspond to the observations on two objects for all $\mathrm{p}$ variables. The quantity $d_{r s}^{2}$ will be referred to as the squared Euclidean distance' (Jobson 1992, p. 487).

Finally, for testing the equality of cluster means, one-way ANOVA has been conducted (Jobson 1992).

Results and discussion

Spatio-temporal variations in cropping intensity

In North Twenty Four Parganas district, cropping intensity increased from $209.29 \%$ in $1996 / 97$ to $228.06 \%$ in $2015 / 16$. During this study period, the increase in cropping intensity was recorded as $8.97 \%$ due to the effective use of modern technological inputs in agriculture (Table 1). Partial correlation indicates that the temporal change in cropping intensity is positively associated with irrigation intensity, the area under HYVs of cereals to total cereals area, and the use of chemical fertilizers (Table 2). During the study period, of these three modern technological inputs, the relationship between cropping intensity and the use of chemical fertilizers is moderately positive and statistically significant. Cropping intensity of 21 Agricultural Blocks in North Twenty Four Parganas district for the years 1996/97 and 2015/16 has been presented in Table 4. In 1996/97, the highest cropping intensity was reported as $277.41 \%$ in Gaighata and the lowest as $110.37 \%$ in Hingalganj Agricultural Blocks. Whereas, in $2015 / 16$, the highest cropping intensity of $271.26 \%$ and the lowest of $111.80 \%$ were recorded in Amdanga and SandeshkhaliII Agricultural Blocks, respectively. Over a period of 20 years, out of 21 Agricultural Blocks in this district, a negative change in cropping intensity was observed in five Agricultural Blocks, namely Sandeshkhali-II, Habra-I, Sandeshkhali-I, Gaighata and Minakhan (Table 4). During the period from 1996/97 to 2015/16, the rate of maximum negative change in cropping intensity was observed as $-23.60 \%$ in Sandeshkhali-II, followed by Habra-I $(-11.34 \%)$ and Sandeshkhali-I (-5.61\%) Agricultural Blocks. A decrease in cropping intensity was observed in these Agricultural Blocks in spite of an increase in the use of modern technological inputs, namely irrigation water, HYVs of cereals and chemical fertilizers in Sandeshkhali-I and Sandeshkhali-II Agricultural Blocks, and the use of HYVs of cereals and chemical fertilizers in Habra-I Agricultural Block (Table 4). This decrease in cropping intensity in these Agricultural Blocks resulted from the occurrence of floods and waterlogged conditions due to heavy rainfall during the monsoon season in 2015 (DMS, North Twenty Four Parganas District 2017).

During the entire study period, the rate of maximum positive change in cropping intensity was reported as $51.57 \%$ in Barasat-I, followed by Barasat-II $(36.46 \%)$ and Barrackpur (33.63\%) Agricultural Blocks. In Barasat-I Agricultural Block, this positive change in cropping intensity is the outcome of the combined effects of the increasing use of irrigation water and of HYVs of cereals and chemical fertilizers. The expansion of the area under irrigation, seeds of HYVs, and the application of chemical fertilizers support multiple cropping which ultimately enhances cropping intensity (Bezbaruah \& Roy 2002). In the case of Barasat-II and Barrackpur Agricultural Blocks, in spite of a decrease in irrigation intensity, cropping intensity increased, resulting from the significant increase in the use of HYVs of cereals and chemical fertilizers (Table 4 ).

Based on the cropping intensity of the Agricultural Blocks North Twenty Four Parganas district was divided into the following three cropping intensity zones for 1996/97 and 2015/16 (Fig. 2).

(i) Low cropping intensity zone (cropping intensity $<164.89 \%$, i.e. $<$ Mean-1SD)

(ii) Moderate cropping intensity zone (cropping intensity 164.89 $-264.03 \%$, i.e. Mean $\pm 1 S D$ ).

(iii) High cropping intensity zone (cropping intensity $>264.03 \%$, i.e. $>$ Mean $+1 S D)$.

In both 1996/97 and 2015/16, three Agricultural Blocks, namely Hingalganj, Minakhan and Sandeshkhali-II, were categorized within the low cropping intensity zone, whereas, during this period Haroa and Hasnabad Agricultural Blocks shifted from the low to moderate zone of cropping intensity. All these five Agricultural Blocks are situated in the Coastal Saline Region, which is part of the Indian Sundarbans delta and prone to severe natural disasters, such as cyclones, erosion and inundation (DPD, 
Table 1. Net cropped area, gross cropped area, gross irrigated area, cropping intensity, irrigation intensity, area under HYVs of cereals to total cereals area and use of chemical fertilizers, i.e. NPK, in North Twenty Four Parganas district (1996/97 to 2015/16)

\begin{tabular}{|c|c|c|c|c|c|c|c|}
\hline Years & $\begin{array}{c}\text { Net Cropped } \\
\text { Area } \\
\text { (hectares)\# }\end{array}$ & $\begin{array}{c}\text { Gross } \\
\text { Cropped } \\
\text { Area } \\
\text { (hectares)\# }\end{array}$ & $\begin{array}{l}\text { Cropping } \\
\text { Intensity } \\
(\%)^{*}\end{array}$ & $\begin{array}{c}\text { Gross } \\
\text { Irrigated Area } \\
\text { (hectares)\# }\end{array}$ & $\begin{array}{l}\text { Irrigation } \\
\text { Intensity } \\
(\%)^{*}\end{array}$ & $\begin{array}{l}\text { Area under HYVs } \\
\text { of Cereals to Total } \\
\text { Cereals Area (\%)\# }\end{array}$ & $\begin{array}{l}\text { Use of Chemical } \\
\text { Fertilizers, i.e. NPK } \\
\text { (kg/hectare)\# }\end{array}$ \\
\hline $1996 / 97$ & 222050 & 464735 & 209.29 & 286032 & 61.55 & 85.81 & 120 \\
\hline $1997 / 98$ & 222050 & 467193 & 210.40 & 286032 & 61.22 & 85.79 & 125 \\
\hline $1998 / 99$ & 222050 & 468525 & 211.00 & 286032 & 61.05 & 84.23 & 144 \\
\hline $1999 / 00$ & 222050 & 471412 & 212.30 & 265894 & 56.4 & 52.94 & 167 \\
\hline $2000 / 01$ & 222050 & 466615 & 210.14 & 194587 & 41.7 & 89.92 & 139 \\
\hline $2001 / 02$ & 222050 & 472966 & 213.00 & 195689 & 41.37 & 90.67 & 151 \\
\hline $2002 / 03$ & 222050 & 455424 & 205.10 & 189720 & 41.66 & 90.6 & 165 \\
\hline $2003 / 04$ & 222050 & 464084 & 209.00 & 198745 & 42.83 & 92.18 & 161 \\
\hline $2004 / 05$ & 222050 & 447852 & 201.69 & 200475 & 44.76 & 92.49 & 173 \\
\hline $2005 / 06$ & 222050 & 500434 & 225.37 & 245178 & 48.99 & 94.4 & 179 \\
\hline $2006 / 07$ & 222050 & 472966 & 213.00 & 189689 & 40.11 & 92.61 & 171 \\
\hline $2007 / 08$ & 225000 & 483750 & 215.00 & 193987 & 40.1 & 95.79 & 165 \\
\hline $2008 / 09$ & 225000 & 503437 & 223.75 & 195940 & 38.92 & 97.09 & 168 \\
\hline $2009 / 10$ & 225000 & 462712 & 205.65 & 195940 & 42.35 & 95.53 & 185 \\
\hline $2010 / 11$ & 225000 & 478597 & 212.71 & 195940 & 40.94 & 92.47 & 188 \\
\hline $2011 / 12$ & 225000 & 479250 & 213.00 & 197058 & 41.12 & 95.37 & 189 \\
\hline $2012 / 13$ & 225000 & 482400 & 214.40 & 198994 & 41.25 & 95.72 & 197 \\
\hline $2013 / 14$ & 220182 & 481097 & 218.50 & 256478 & 53.31 & 96.09 & 217 \\
\hline $2014 / 15$ & 220182 & 493207 & 224.00 & 287459 & 58.28 & 95.97 & 224 \\
\hline $2015 / 16$ & 220182 & 502154 & 228.06 & 311109 & 61.95 & 96.93 & 230 \\
\hline
\end{tabular}

Sources:

* Calculated by the authors.

\# Office of the Deputy Directorate of Agriculture (Admn.), Government of West Bengal, Barasat, North Twenty Four Parganas District, West Bengal, India.

Table 2. Partial correlation between cropping intensity and selected independent variables

\begin{tabular}{|c|c|c|c|c|}
\hline Dependent Variable & Independent Variables* & Correlation & $\begin{array}{l}\text { Significance } \\
\text { (2-tailed) }\end{array}$ & Degrees of Freedom \\
\hline \multirow{3}{*}{$\begin{array}{l}\text { Cropping Intensity } \\
\qquad(\%)\end{array}$} & Irrigation Intensity (\%) & 0.363 & 0.138 & 16 \\
\hline & $\begin{array}{l}\text { Area under HYVs of Cereals to Total Cereals } \\
\text { Area }(\%)\end{array}$ & 0.210 & 0.402 & 16 \\
\hline & $\begin{array}{l}\text { Use of Chemical Fertilizers, i.e. NPK } \\
\qquad(\mathrm{kg} / \text { hectare })\end{array}$ & 0.500 & $0.035^{\star *}$ & 16 \\
\hline
\end{tabular}

* partial correlation with each of the independent variables is done taking rests as control variables.

${ }^{* *}$ statistically significant at $5 \%$ level. 
MISCELLANEA GEOGRAPHICA - REGIONAL STUDIES ON DEVELOPMENT

Vol. $25 \cdot$ No. $4 \cdot 2021 \cdot$ pp. 246-258 •ISSN: 2084-6118 • DOI: 10.2478/mgrsd-2020-0063

Table 3. Agro-ecological regions, density of rural population, net cropped area, gross cropped area and gross irrigated area in North Twenty Four Parganas district

\begin{tabular}{|c|c|c|c|c|c|c|c|c|c|c|c|}
\hline \multirow[t]{2}{*}{$\begin{array}{l}\text { SI. } \\
\text { Nos. }\end{array}$} & \multirow[t]{2}{*}{$\begin{array}{l}\text { Agricultural } \\
\text { Blocks }\end{array}$} & \multirow{2}{*}{$\begin{array}{c}\text { Agro- } \\
\text { Ecological } \\
\text { Regions } \\
\text { (area in km²) }\end{array}$} & \multicolumn{3}{|c|}{$\begin{array}{l}\text { Density of Rural } \\
\text { Population* } \\
\text { (persons/km²) }\end{array}$} & \multicolumn{2}{|c|}{$\begin{array}{l}\text { Net Cropped Area } \\
\text { (hectares)\# }\end{array}$} & \multicolumn{2}{|c|}{$\begin{array}{l}\text { Gross Cropped } \\
\text { Area (hectares)\# }\end{array}$} & \multicolumn{2}{|c|}{$\begin{array}{l}\text { Gross Irrigated } \\
\text { Area (hectares)\# }\end{array}$} \\
\hline & & & 1991 & 2001 & 2011 & $1996 / 97$ & $2015 / 16$ & $1996 / 97$ & $2015 / 16$ & $1996 / 97$ & $2015 / 16$ \\
\hline 1 & Amdanga & \multirow{11}{*}{$\begin{array}{c}\text { Gangetic Plains } \\
(1410.35)\end{array}$} & 1001 & 1190 & 1364 & 8995 & 8995 & 19794 & 24400 & 13502 & 15923 \\
\hline 2 & Barasat-I & & 1593 & 2146 & 2146 & 6320 & 6320 & 11270 & 17082 & 5625 & 9564 \\
\hline 3 & Barasat-II & & 1295 & 1483 & 1710 & 9730 & 9730 & 18603 & 25385 & 10660 & 14259 \\
\hline 4 & Barrackpur & & 1562 & 1763 & 1715 & 7570 & 7570 & 14647 & 19574 & 9120 & 10768 \\
\hline 5 & Deganga & & 1143 & 1362 & 1553 & 12000 & 12569 & 26397 & 30996 & 21000 & 22289 \\
\hline 6 & Habra-I & & 1027 & 1472 & 1646 & 8808 & 8808 & 20677 & 18333 & 14745 & 10765 \\
\hline 7 & Habra-II & & 837 & 1226 & 1344 & 8000 & 8000 & 19268 & 21109 & 17104 & 12802 \\
\hline 8 & Rajarhat & & 1749 & 1945 & 1835 & 3958 & 1370 & 8318 & 3565 & 3015 & 2554 \\
\hline 9 & Baduria & & 1008 & 1378 & 1567 & 12390 & 13490 & 32818 & 35924.5 & 25820 & 21200 \\
\hline 10 & Basirhat-I & & 1090 & 1321 & 1436 & 7400 & 9133 & 15860 & 20058 & 8800 & 11123 \\
\hline 11 & Basirhat-II & & 1224 & 1507 & 1715 & 8595 & 8174 & 17627 & 19076 & 9687 & 10801 \\
\hline 12 & Haroa & \multirow{6}{*}{$\begin{array}{c}\text { Coastal } \\
\text { Saline Region } \\
(1028.62)\end{array}$} & 989 & 1195 & 1403 & 9100 & 8953 & 14725 & 19038 & 7785 & 9713 \\
\hline 13 & Hasnabad & & 972 & 1160 & 1306 & 11020 & 8600 & 17067 & 16000 & 7570 & 7812 \\
\hline 14 & Hingalganj & & 618 & 655 & 694 & 14200 & 14200 & 15673 & 16506 & 4880 & 5910 \\
\hline 15 & Minakhan & & 874 & 1064 & 1267 & 11400 & 7194 & 15608 & 9570.5 & 6665 & 3895 \\
\hline 16 & Sandeshkhali-I & & 665 & 771 & 902 & 8064 & 7559 & 14334 & 12681.5 & 6600 & 6556 \\
\hline 17 & Sandeshkhali-II & & 603 & 691 & 816 & 7730 & 9830 & 11312 & 10990 & 3620 & 3865 \\
\hline 18 & Swarupnagar & \multirow{4}{*}{$\begin{array}{c}\text { Ichhamati } \\
\text { Basin (1082.91) }\end{array}$} & 917 & 1054 & 1179 & 13120 & 13083 & 32299 & 34276 & 26210 & 19445 \\
\hline 19 & Bagdah & & 819 & 941 & 1041 & 14800 & 17754 & 34115 & 43128.3 & 27310 & 33443 \\
\hline 20 & Bongaon & & 874 & 1022 & 1131 & 22940 & 22940 & 60187 & 61494.5 & 30074 & 44291 \\
\hline 21 & Gaighata & & 1021 & 1187 & 1173 & 15910 & 15910 & 44136 & 42966.2 & 26240 & 34131 \\
\hline \multicolumn{3}{|c|}{ District Total } & 980 & 1171 & 1277 & 222050 & 220182 & 464735 & 502154 & 286032 & 311109 \\
\hline
\end{tabular}

Sources:

* Government of India (Gol) 2011, Office of the Registrar General \& Census Commissioner, Ministry of Home Affairs, Census of India, 1991,2001 and 2011, India. Available from: <https://censusindia.gov.in> [20 June 2019].

\# Office of the Deputy Directorate of Agriculture (Admn.), Government of West Bengal, Barasat, North Twenty Four Parganas District, West Bengal, India.

GoWB 2010). Monocropped areas dominate in this delta region due to the high salinity in the soil and water and an uneconomic underground irrigation system (Guha 2000). During this study period, the cropping intensity increased in Haroa Agricultural Block, resulting from the increasing use of HYVs of cereals and chemical fertilizers, whereas in Hasnabad Agricultural Block the increase in irrigation intensity and use of HYVs of cereals and chemical fertilizers enhanced cropping intensity (Table 4).

During the study period, three Agricultural Blocks, namely Amdanga, Barasat-I and Bongaon, shifted from moderate to high cropping intensity zones. In Amdanga and Barasat-I Agricultural Blocks, although irrigation decreased slightly, the use of HYVs of cereals and chemical fertilizers increased during this period.
The increase in the use of modern technological inputs may be attributed as the reason Bongaon Agricultural Block moved from a medium to a high cropping intensity zone. In this Agricultural Block, irrigation intensity increased by $44.13 \%$, the use of chemical fertilizers by $95.96 \%$, and HYVs of cereals by $3.36 \%$ during this period (Table 4). Baduria and Gaighata Agricultural Blocks maintained their high status of cropping intensity and the remaining 11 Agricultural Blocks retained their moderate status of cropping intensity during the study period. In 1996/97, the irrigation intensity, the area under HYVs of cereals and the use of chemical fertilizers in Baduria Agricultural Block were higher than the district average. Whereas, in Gaighata Agricultural Block, the area under HYVs of cereals and the use of chemical fertilizers 
Table 4. Cropping intensity $(X)$, irrigation intensity $(Y)$, residuals ( $X$ and $Y)$, area under HYVs of cereals to total cereals area and use of chemical fertilizers, i.e. NPK, in North Twenty Four Parganas district (1996/97 and 2015/16)

\begin{tabular}{|c|c|c|c|c|c|c|c|c|c|c|c|}
\hline \multirow{2}{*}{$\begin{array}{l}\text { SI. } \\
\text { Nos. }\end{array}$} & \multirow{2}{*}{$\begin{array}{l}\text { Agricultural } \\
\text { Blocks }\end{array}$} & \multicolumn{2}{|c|}{$\begin{array}{c}\text { Cropping } \\
\text { Intensity }(\%) X^{*}\end{array}$} & \multicolumn{2}{|c|}{$\begin{array}{l}\text { Irrigation Intensity } \\
(\%) Y^{*}\end{array}$} & \multicolumn{2}{|c|}{$\begin{array}{l}\text { Residuals } \\
(X \text { and } Y)^{*}\end{array}$} & \multicolumn{2}{|c|}{$\begin{array}{l}\text { Area under HYVs } \\
\text { of Cereals to Total } \\
\text { Cereals Area (\%)\# }\end{array}$} & \multicolumn{2}{|c|}{$\begin{array}{l}\text { Use of Chemical } \\
\text { Fertilizers i.e. NPK } \\
\text { (kg/hectare)\# }\end{array}$} \\
\hline & & $1996 / 97$ & $2015 / 16$ & $1996 / 97$ & $2015 / 16$ & $1996 / 97$ & $2015 / 16$ & $1996 / 97$ & $2015 / 16$ & $1996 / 97$ & $2015 / 16$ \\
\hline 1 & Amdanga & 220.06 & 271.26 & 68.21 & 65.26 & -2.3 & 20.71 & 86.37 & 98.43 & 124.63 & 223.87 \\
\hline 2 & Barasat-I & 178.32 & 270.28 & 49.91 & 55.99 & -9.89 & 51.53 & 90.51 & 98.96 & 140.37 & 246.5 \\
\hline 3 & Barasat-II & 191.19 & 260.89 & 57.3 & 56.17 & -10.81 & 41.52 & 82.44 & 98.19 & 119.82 & 240.68 \\
\hline 4 & Barrackpur & 193.49 & 258.57 & 62.27 & 55.01 & -17.77 & 43.17 & 86.99 & 95.06 & 147.81 & 292.58 \\
\hline 5 & Deganga & 219.98 & 246.61 & 79.55 & 71.91 & -23.54 & -26.77 & 91.11 & 99.55 & 143.69 & 244.91 \\
\hline 6 & Habra-I & 234.75 & 208.14 & 71.31 & 58.72 & 6.62 & -19.98 & 95.19 & 100.00 & 171.88 & 308.82 \\
\hline 7 & Habra-II & 240.85 & 263.86 & 88.77 & 60.65 & -19.85 & 29.13 & 95.02 & 99.60 & 132.71 & 267.94 \\
\hline 8 & Rajarhat & 210.16 & 260.22 & 36.25 & 71.64 & 47.43 & -12.24 & 86.41 & 98.44 & 145.11 & 360.45 \\
\hline 9 & Baduria & 264.87 & 266.3 & 78.68 & 59.01 & 23 & 37.18 & 95.39 & 99.14 & 155.04 & 233.36 \\
\hline 10 & Basirhat-I & 214.32 & 219.62 & 55.49 & 55.45 & 15.71 & 2.7 & 93.41 & 99.36 & 129.26 & 221.28 \\
\hline 11 & Basirhat-II & 205.08 & 233.37 & 54.96 & 56.62 & 7.46 & 12.45 & 90.79 & 98.00 & 143.13 & 241.46 \\
\hline 12 & Haroa & 161.81 & 212.64 & 52.87 & 51.02 & -31.92 & 10.95 & 71.68 & 91.84 & 100.92 & 209.61 \\
\hline 13 & Hasnabad & 154.87 & 186.05 & 44.35 & 48.83 & -22.98 & -8.12 & 78.34 & 99.88 & 64.74 & 203.19 \\
\hline 14 & Hingalganj & 110.37 & 116.24 & 31.14 & 35.81 & -42.82 & -33.26 & 64.37 & 90.67 & 42.88 & 150.39 \\
\hline 15 & Minakhan & 136.91 & 133.03 & 42.7 & 40.7 & -37.85 & -33.25 & 77.35 & 92.85 & 87.58 & 165.34 \\
\hline 16 & Sandeshkhali-I & 177.75 & 167.77 & 46.04 & 51.7 & -3.25 & -36.26 & 67.53 & 95.32 & 83.93 & 171.73 \\
\hline 17 & Sandeshkhali-II & 146.34 & 111.8 & 32 & 35.17 & -8.47 & -35.51 & 42.68 & 76.57 & 59.67 & 153.37 \\
\hline 18 & Swarupnagar & 246.18 & 261.99 & 81.15 & 56.73 & -0.3 & 40.69 & 84.89 & 100.00 & 120.13 & 217.01 \\
\hline 19 & Bagdah & 230.51 & 242.92 & 80.05 & 77.54 & -13.93 & -49.79 & 93.8 & 99.48 & 106.26 & 214.49 \\
\hline 20 & Bongaon & 262.37 & 268.07 & 49.97 & 72.02 & 74.05 & -5.71 & 95.05 & 98.24 & 117.93 & 231.09 \\
\hline 21 & Gaighata & 277.41 & 270.06 & 59.45 & 79.44 & 71.4 & -29.15 & 93.72 & 100.00 & 127.42 & 240.94 \\
\hline \multicolumn{2}{|c|}{ District Total } & 209.29 & 228.06 & 61.55 & 61.95 & - & - & 85.81 & 96.93 & 120.39 & 230.11 \\
\hline
\end{tabular}

\section{Sources:}

${ }^{*}$ Calculated by the authors.

\# Office of the Deputy Directorate of Agriculture (Admn.), Government of West Bengal, Barasat, North Twenty Four Parganas

District, West Bengal, India.

were higher than the district average. In 2015/16, irrigation intensity was slightly lower than the district average in Baduria Agricultural Block; however, this Block maintained high cropping intensity due to an increase in the use of chemical fertilizers and HYVs of cereals.

From 1996/97 to 2015/16, the net cropped area in this district decreased by 1,868 hectares, whereas the gross cropped area increased by $37,418.5$ hectares. The conversion of agricultural land for shrimp cultivation, brick kilns and the occurrences of natural calamities were responsible for this reduction of net cropped area (DPD, GoWB 2010). In addition, agricultural land was reduced due to the expansion of urban settlements and commercial activities in this district (Dhali, Chakraborty \& Sahana 2019; Bera \& Das Chatterjee 2019; Das \& Angadi 2020, Dhar et al. 2019). However, with the significant use of modern technological inputs in agriculture, cropping intensity increased in this district from $1996 / 97$ to $2015 / 16$. During this period, the increase was reported as $0.65 \%$ in irrigation intensity, $12.96 \%$ in the area under HYVs of cereals, and $91.66 \%$ in the use of chemical fertilizers in the entire district (Table 1). 

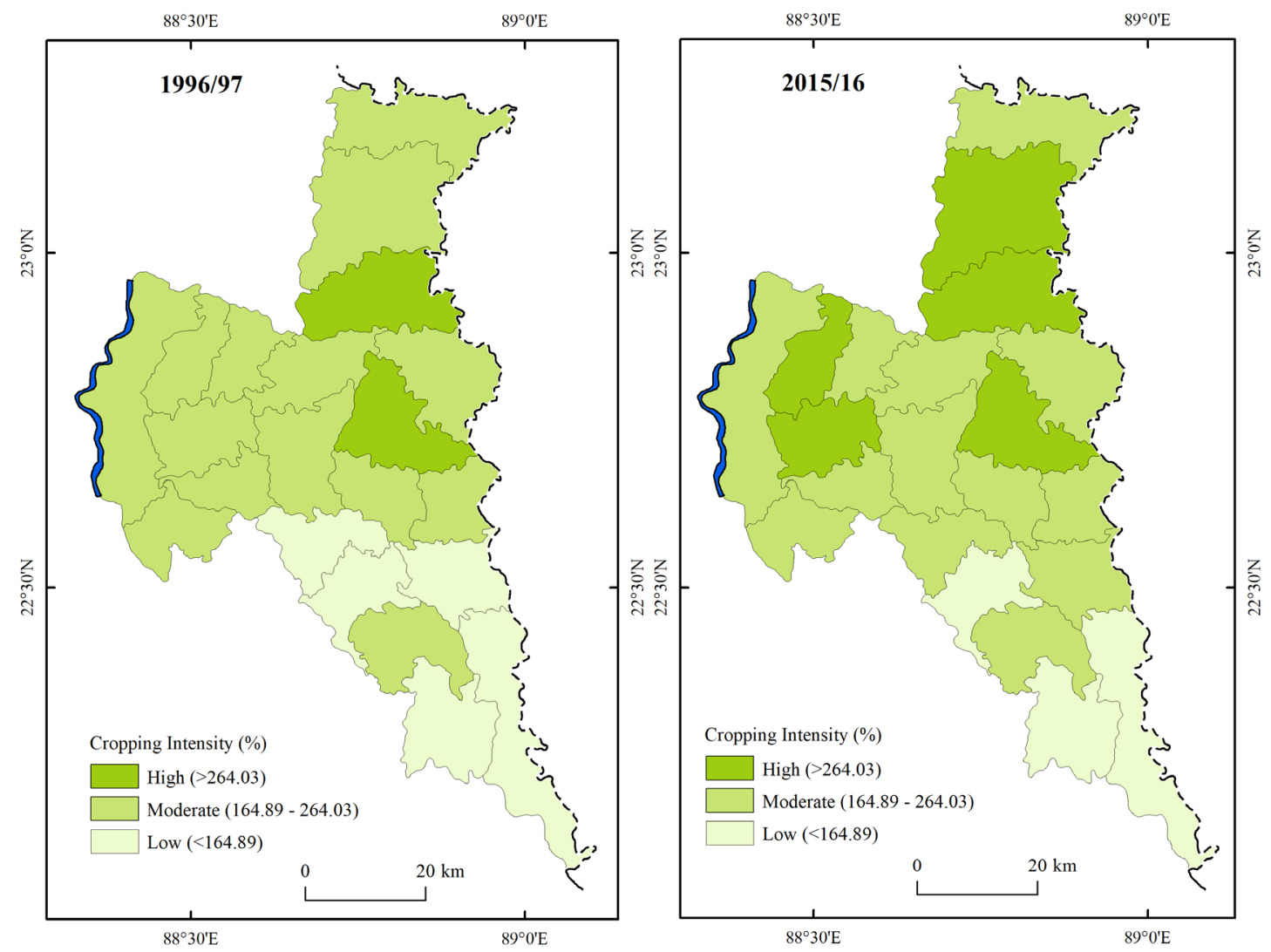

Figure 2. Cropping intensity zones in North Twenty Four Parganas district (1996/97 and 2015/16) Source: authors' maps based on data obtained from the Office of the Deputy Directorate of Agriculture (Admn.), GoWB, Barasat, North Twenty Four Parganas District, West Bengal, India

\section{Spatio-temporal variations in irrigation intensity}

In North Twenty Four Parganas district, the main source of irrigation water is ground water, which contributes to $93.28 \%$ of the total gross irrigated area in the district (DLIC, PMKSY \& DM, North Twenty Four Parganas 2016). Irrigation intensity in this district was reported as $61.55 \%$ in $1996 / 97$ and $61.95 \%$ in 2015/16 (Table 1). In 1996/97, the highest irrigation intensity was observed as $88.77 \%$ in Habra-II and the lowest as $31.14 \%$ in Hingalganj Agricultural Blocks. The highest irrigation intensity was found to be $79.44 \%$ in Gaighata and the lowest to be $35.17 \%$ in Sandeshkhali-II Agricultural Blocks in 2015/16 (Table 4). This study has revealed that intra district variations in irrigation intensity are highly perceptible; however, the progress in irrigation development in the entire district is almost constant.

Based on irrigation intensity, North Twenty Four Parganas district has been divided into the following three irrigation intensity zones for the years 1996/97 and 2015/16 (Fig. 3).

(i) Low irrigation intensity zone (irrigation intensity $<43.43 \%$, i.e. $<$ Mean-1SD)

(ii) Moderate irrigation intensity zone (irrigation intensity $43.43 \%$ $-72.66 \%$, i.e. Mean $\pm 1 S D$ ).

(iii) High irrigation intensity zone (irrigation intensity $>72.66 \%$, i.e. $>$ Mean $+1 S D)$.

During the study period, a negative change in irrigation intensity was reported in 12 Agricultural Blocks and a positive change in the remaining nine Agricultural Blocks in this district. From $1996 / 97$ to $2015 / 16$, the maximum rate of negative change in irrigation intensity was found to be $-31.68 \%$ in HabraII, followed by Swarupnagar (-30.09\%) and Baduria (-25\%) Agricultural Blocks. During this period, the maximum rate of positive change in irrigation intensity was observed as $97.63 \%$ in Rajarhat, followed by Bongaon (44.13\%) and Gaighata (33.62\%) Agricultural Blocks.

Agricultural Blocks in the Coastal Saline Region suffer mostly from a paucity of irrigation water. In this region, out of the total gross cropped area, only $41.84 \%$ in $1996 / 97$ and $44.53 \%$ in $2015 / 16$ were irrigated. More than $50 \%$ of agricultural lands were kept as fallow lands, after harvesting the rainfed paddy grown in monsoon season in this region (DLIC, PMKSY \& DM, North Twenty Four Parganas 2016).

Relationship between irrigation intensity and cropping intensity

Two residual maps have been drawn to examine the relationship between cropping intensity and irrigation intensity in the study area for the years $1996 / 97$ and 2015/16 (Fig. 4). The residual lines with ' 0 ' value on the map indicate the perfect relationship between cropping intensity and irrigation intensity. The areas with positive residual values on the map mean that both the agro-ecological conditions and the use of modern technological inputs in agriculture, apart from irrigation water, are conducive to increasing cropping intensity. Areas with negative residual values denote that, in spite of the use of irrigation water, cropping intensity is not substantial, which may be attributed to the adverse agro-ecological conditions and the use of other farm inputs at a lower rate. 

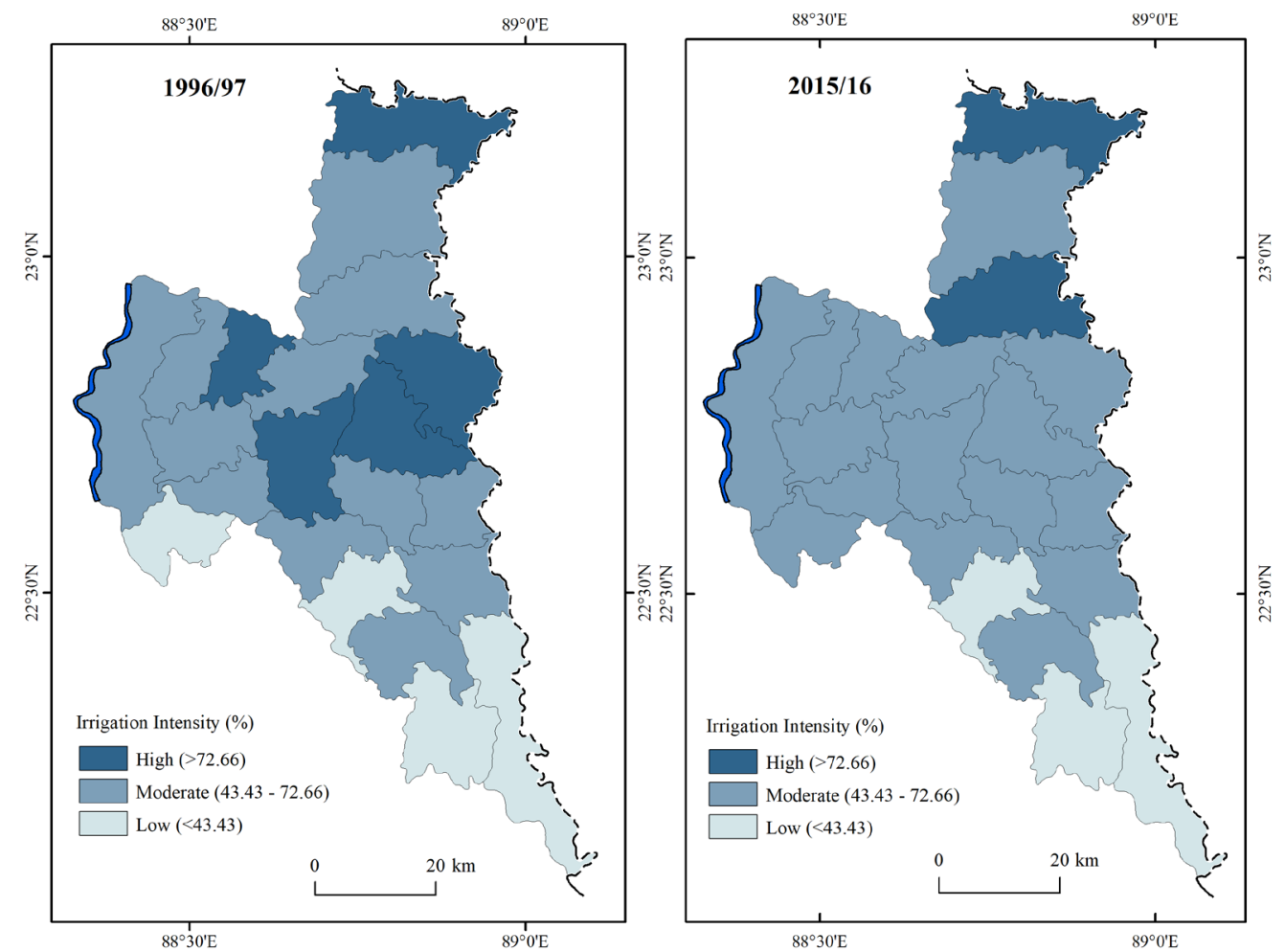

Figure 3. Irrigation intensity zones in North Twenty Four Parganas district (1996/97 and 2015/16)

Source: authors' maps based on data obtained from the Office of the Deputy Directorate of Agriculture (Admn.), GoWB, Barasat, North Twenty Four Parganas District, West Bengal, India
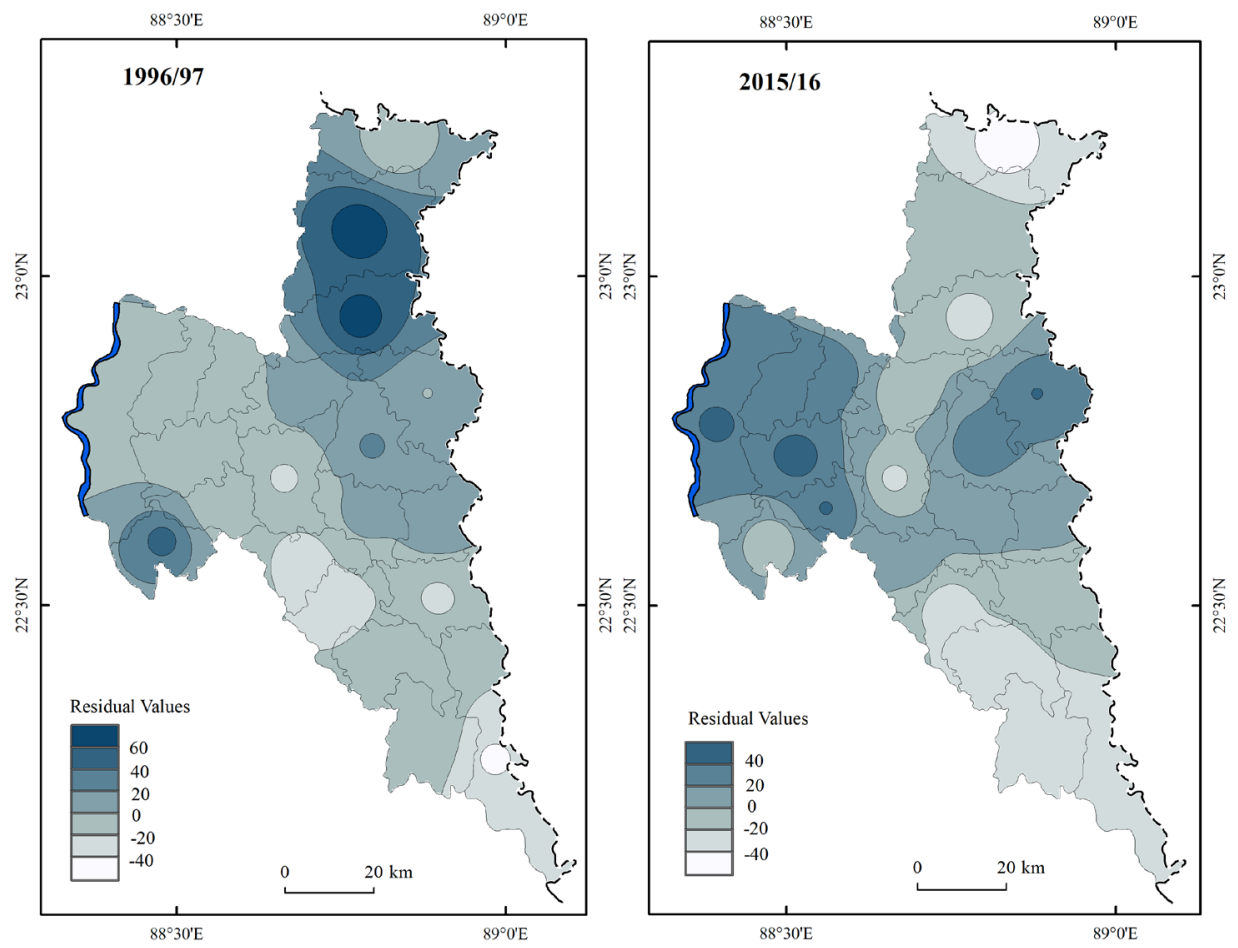

Figure 4. Relationship between irrigation intensity and cropping intensity in North Twenty Four Parganas district (1996/97 and 2015/16)

Source: authors' maps based on data obtained from the Office of the Deputy Directorate of Agriculture (Admn.), GoWB, Barasat, North Twenty Four Parganas District, West Bengal, India 
MISCELLANEA GEOGRAPHICA - REGIONAL STUDIES ON DEVELOPMENT

Vol. $25 \cdot$ No. $4 \cdot 2021 \cdot$ pp. 246-258 •ISSN: 2084-6118 • DOI: 10.2478/mgrsd-2020-0063

Table 5. Cluster criteria and association of Agricultural Blocks in North Twenty Four Parganas district (1996/97 and 2015/16)

\begin{tabular}{|c|c|c|c|}
\hline \multirow{2}{*}{ Clusters } & Cluster Criteria & 1996/97 & 2015/16 \\
\cline { 3 - 4 } & $\begin{array}{c}\text { Moderate to high cropping } \\
\text { intensity and irrigation } \\
\text { intensity }\end{array}$ & $\begin{array}{c}\text { Amdanga, Deganga, Habra-I, } \\
\text { Habra-II, Baduria, Swarupnagar } \\
\text { and Bagdah }\end{array}$ & $\begin{array}{c}\text { Amdanga, Barasat-I, Barasat-II, Barrackpur, } \\
\text { Deganga, Habra-II, Rajarhat, Baduria, } \\
\text { Swarupnagar, Bagdah, Bongaon and Gaighata }\end{array}$ \\
\hline 2 & $\begin{array}{c}\text { Moderate cropping } \\
\text { intensity and irrigation } \\
\text { intensity }\end{array}$ & $\begin{array}{c}\text { Barasat-I, Rajarhat, Haora, } \\
\text { Hasnabad, Hingalganj, Minakhan, } \\
\text { Sandeshkhali-I and Sandeshkhali-II }\end{array}$ & $\begin{array}{r}\text { Habra-I, Basirhat-I, Basirhat-II, Haroa, Hasnabad } \\
\text { and Sandeshkhali-I }\end{array}$ \\
\hline 3 & $\begin{array}{c}\text { Low cropping intensity } \\
\text { and moderate irrigation } \\
\text { intensity }\end{array}$ & $\begin{array}{c}\text { Barasat-II, Barrackpur, Basirhat-I, } \\
\text { Basirhat-II, Bongaon and Gaighata }\end{array}$ & Hingalganj, Minakhan and Sandeshkhali-II \\
\hline
\end{tabular}

Sources: calculated by the authors

Table 6. ANOVA (1996/97)

\begin{tabular}{|c|c|c|c|c|c|c|}
\hline & & Sum of Squares & df & Mean Square & $\mathbf{F}$ & Sig. \\
\hline \multirow{3}{*}{$\begin{array}{c}\text { Cropping Intensity } \\
(1996 / 97)\end{array}$} & Between Groups & 25691.975 & 2 & 12845.987 & 15.772 & .000 \\
\hline & Within Groups & 14660.781 & 18 & 814.488 & & \\
\hline & Total & 40352.756 & 20 & & & \\
\hline \multirow{3}{*}{$\begin{array}{l}\text { Irrigation Intensity } \\
\qquad(1996 / 97)\end{array}$} & Between Groups & 4952.253 & 2 & 2476.127 & 54.635 & .000 \\
\hline & Within Groups & 815.789 & 18 & 45.322 & & \\
\hline & Total & 5768.042 & 20 & & & \\
\hline
\end{tabular}

Sources: calculated by the authors

In 1996/97, residual lines with '0' values passed through Bagdah, Basirhat-I, Basirhat-II, Deganga, Habra-II and Rajarhat, Barasat-I, Barasat-II and Barrackpur Agricultural Blocks in the district. Positive lines crossed through Rajarhat, Bagdah, Bongaon, Gaighata and the central part of Baduria Agricultural Blocks, and negative lines passed through the Agricultural Blocks lying in the Indian Sundarbans delta and the central part of Deganga Agricultural Block.

In 2015/16, the relationship between irrigation intensity and cropping intensity changed in the district. In this period, ' $O$ ' residual lines passed through Gaighata, Deganga, Habra-I, Basirhat-I, Basirhat-II, Haroa and Rajarhat Agricultural Blocks. Residual lines with positive values passed through Swarupnagar and Baduria Agricultural Blocks and the western part of the district. Residual lines with negative values crossed through the northern and southern parts of this district.

The hierarchical clustering using the Ward method, based on two cluster variables, namely irrigation intensity and cropping intensity, was performed to show the nature of homogeneity of the 21 Agricultural Blocks in North Twenty Four Parganas district for the years 1996/97 and 2015/16. Three clusters with cluster criteria, and their corresponding Agricultural Blocks in the study area, are presented in Table 5.

One-way ANOVA was conducted to determine the significant differences in the mean scores of cropping intensity and irrigation intensity across three clusters (i.e. cluster-1, 2 and 3 ) for the years 1996/97 and 2015/16, respectively.

From the Test of Homogeneity of Variances, it is evident that the Levene's tests are not significant at 0.05 alpha level for both of the dependent variables (i.e. $p=0.104$ for cropping intensity and $p=0.244$ for irrigation intensity) in 1996/97. The ANOVA results in 1996/97 (Table 6) confirmed that the null hypothesis (i.e. all three clusters means are equal) is rejected in both cases. Hence, there are significant differences between clusters means in every case (for cropping intensity and irrigation intensity, $p$ $=0.000$, i.e. $<0.05$ )

Post-hoc tests (Tukey HSD) were conducted to identify which group mean was significantly different from each of the others (Table 7). It was confirmed, from the results of Posthoc tests on cropping intensity, that cluster-1 is significantly different from cluster-2. Likewise, in cropping intensity, cluster-2 is significantly different from cluster-3. In cropping intensity, there is no statistically significant difference between cluster-1 and cluster-3. The Eta squared $\left(\eta^{2}\right)$ is calculated as 0.6367 , i.e. $63.67 \%$ variance is associated with cropping intensity.

In 1996/97, for irrigation intensity (Table 7), cluster-1 is significantly different from cluster-2. Cluster-1 is significantly different from cluster-3. Cluster-2 is significantly different from cluster-3. The Eta squared $\left(\eta^{2}\right)$ is calculated as 0.8586 , i.e. $85.86 \%$ variance is associated with irrigation intensity in 1996/97.

From the Test of Homogeneity of Variances, it is evident that the Levene's tests are significant at 0.05 alpha level for both of the dependent variables (i.e. $p=0.029$ for cropping intensity and $p=.005$ for irrigation intensity) in $2015 / 16$. Therefore, the assumption of homogeneity of variance was violated in both cases. Hence, Robust Tests of Equality of Means (Welch and Brown-Forsythe) were conducted (Table 8 ) and the adjusted $F$ ratio in all cases were significant (i.e. $p<0.001$ ) and, therefore, the null hypothesis was rejected. The Welch and BrownForsythe tests results confirmed that there were significant mean 


\begin{tabular}{|c|c|c|c|c|c|c|c|}
\hline \multicolumn{8}{|c|}{ Tukey HSD (Multiple Comparisons) } \\
\hline \multirow{2}{*}{$\begin{array}{l}\text { Dependent } \\
\text { Variable }\end{array}$} & \multirow{2}{*}{$\begin{array}{l}\text { (I) Ward } \\
\text { Method }\end{array}$} & \multirow{2}{*}{$\begin{array}{l}\text { (J) Ward } \\
\text { Method }\end{array}$} & \multirow{2}{*}{$\begin{array}{c}\text { Mean Difference } \\
(\mathrm{I}-\mathrm{J})\end{array}$} & \multirow{2}{*}{ Std. Error } & \multirow{2}{*}{ Sig. } & \multicolumn{2}{|c|}{ 95\% Confidence Interval } \\
\hline & & & & & & Lower Bound & Upper Bound \\
\hline \multirow{6}{*}{$\begin{array}{l}\text { Cropping } \\
\text { Intensity } \\
(1996 / 97)\end{array}$} & \multirow{2}{*}{1} & 2 & $77.17661^{*}$ & 14.77046 & .000 & 39.4800 & 114.8732 \\
\hline & & 3 & 12.76619 & 15.87776 & .705 & -27.7565 & 53.2888 \\
\hline & \multirow{2}{*}{2} & 1 & $-77.17661^{*}$ & 14.77046 & .000 & -114.8732 & -39.4800 \\
\hline & & 3 & $-64.41042^{*}$ & 15.41295 & .002 & -103.7468 & -25.0741 \\
\hline & \multirow{2}{*}{3} & 1 & -12.76619 & 15.87776 & .705 & -53.2888 & 27.7565 \\
\hline & & 2 & $64.41042^{*}$ & 15.41295 & .002 & 25.0741 & 103.7468 \\
\hline \multirow{6}{*}{$\begin{array}{l}\text { Irrigation } \\
\text { Intensity } \\
(1996 / 97)\end{array}$} & \multirow{2}{*}{1} & 2 & $36.33821^{*}$ & 3.48421 & .000 & 27.4459 & 45.2305 \\
\hline & & 3 & $21.67238^{*}$ & 3.74541 & .000 & 12.1135 & 31.2313 \\
\hline & \multirow{2}{*}{2} & 1 & $-36.33821^{*}$ & 3.48421 & .000 & -45.2305 & -27.4459 \\
\hline & & 3 & $-14.66583^{*}$ & 3.63577 & .002 & -23.9449 & -5.3868 \\
\hline & \multirow{2}{*}{3} & 1 & $-21.67238^{*}$ & 3.74541 & .000 & -31.2313 & -12.1135 \\
\hline & & 2 & $14.66583^{*}$ & 3.63577 & .002 & 5.3868 & 23.9449 \\
\hline
\end{tabular}

* The mean difference is significant at the 0.05 level. Sources: calculated by the authors

Table 8. Robust Tests of Equality of Means (2015/16)

\begin{tabular}{|l|c|c|c|c|c|}
\hline \multicolumn{2}{|c|}{} & Statistic & df1 & df2 & Sig. \\
\hline \multirow{2}{*}{ Cropping Intensity (2015/16) } & Welch & 186.750 & 2 & 4.780 & .000 \\
\cline { 2 - 7 } & Brown-Forsythe & 94.294 & 2 & 7.745 & .000 \\
\hline \multirow{2}{*}{ Irrigation Intensity (2015/16) } & Welch & 43.072 & 2 & 8.316 & .000 \\
\cline { 2 - 7 } & Brown-Forsythe & 38.153 & 2 & 17.286 & .000 \\
\hline
\end{tabular}

Sources: calculated by the authors

differences between clusters for cropping intensity and irrigation intensity in 2015/16.

The Games-Howell test was conducted as the Post-hoc tests in 2015/16, as the equal variance was not assumed (Table 9). In 2015/16, the results of Post-hoc tests (Games-Howell) on cropping intensity show cluster-1 is significantly different from cluster-2. Cluster-1 is significantly different from cluster-3 in cropping intensity. In cropping intensity, cluster-2 is significantly different from cluster-3. The Eta squared $\left(\eta^{2}\right)$ is calculated as 0.9284 , i.e. $92.84 \%$ variance is associated with cropping intensity in $2015 / 16$.

In comparison, cluster-1 is significantly different from cluster-2 in irrigation intensity in $2015 / 16$. Cluster- 1 is significantly different from cluster-3 in irrigation intensity. Cluster-2 is significantly different from cluster- 3 in irrigation intensity. The Eta squared $\left(\eta^{2}\right)$ is calculated as 0.6726 , i.e. $67.26 \%$ variance is associated with irrigation intensity in 2015/16.
Conclusions

The analysis of cropping intensity and irrigation intensity in North Twenty Four Parganas district from 1996/97 to 2015/16 re-establishes the positive correlation between them. However, considering the temporal and spatial dimensions of this relationship within this district, the following two significant observations were obtained from this study. First, during the study period, the district as a whole reflected a low positive correlation between cropping intensity and irrigation intensity. This trend, derived from the partial correlation among various associated factors with cropping intensity, clearly indicates that cropping intensity in this district was also influenced by other technological inputs, most significantly chemical fertilizers and HYV seeds of cereals, along with irrigation. Second, considering the spatial (Agricultural Block level) variations, two different trends in the relationship between cropping intensity and irrigation intensity were observed in North Twenty Four Parganas district during 
MISCELLANEA GEOGRAPHICA - REGIONAL STUDIES ON DEVELOPMENT

Vol. 25 • No. 4 • 2021 • pp. 246-258 • ISSN: 2084-6118 • DOI: 10.2478/mgrsd-2020-0063

Table 9. Post-hoc Tests (2015/16)

\begin{tabular}{|c|c|c|c|c|c|c|c|}
\hline \multicolumn{8}{|c|}{ Games-Howell (Multiple Comparisons) } \\
\hline \multirow{2}{*}{$\begin{array}{l}\text { Dependent } \\
\text { Variable }\end{array}$} & \multirow{2}{*}{$\begin{array}{l}\text { (I) Ward } \\
\text { Method }\end{array}$} & \multirow{2}{*}{$\begin{array}{c}(\mathrm{J}) \\
\text { Ward Method }\end{array}$} & \multirow{2}{*}{$\begin{array}{c}\text { Mean Difference } \\
(\mathrm{I}-\mathrm{J})\end{array}$} & \multirow{2}{*}{ Std. Error } & \multirow{2}{*}{ Sig. } & \multicolumn{2}{|c|}{$95 \%$ Confidence Interval } \\
\hline & & & & & & Lower Bound & Upper Bound \\
\hline \multirow{6}{*}{$\begin{array}{l}\text { Cropping } \\
\text { Intensity } \\
(2015 / 16)\end{array}$} & \multirow{2}{*}{1} & 2 & $57.15417^{\star}$ & 10.05702 & .004 & 25.8715 & 88.4369 \\
\hline & & 3 & $141.39583^{*}$ & 6.96935 & .001 & 109.9476 & 172.8441 \\
\hline & \multirow{2}{*}{2} & 1 & $-57.15417^{*}$ & 10.05702 & .004 & -88.4369 & -25.8715 \\
\hline & & 3 & $84.24167^{*}$ & 11.66894 & .000 & 49.8575 & 118.6259 \\
\hline & \multirow{2}{*}{3} & 1 & $-141.39583^{*}$ & 6.96935 & .001 & -172.8441 & -109.9476 \\
\hline & & 2 & $-84.24167^{*}$ & 11.66894 & .000 & -118.6259 & -49.8575 \\
\hline \multirow{6}{*}{$\begin{array}{l}\text { Irrigation } \\
\text { Intensity } \\
(2015 / 16)\end{array}$} & \multirow{2}{*}{1} & 2 & $11.39083^{*}$ & 3.02058 & .005 & 3.5875 & 19.1941 \\
\hline & & 3 & $27.88750^{\star}$ & 3.12802 & .000 & 19.4289 & 36.3461 \\
\hline & \multirow{2}{*}{2} & 1 & $-11.39083^{*}$ & 3.02058 & .005 & -19.1941 & -3.5875 \\
\hline & & 3 & $16.49667^{\star}$ & 2.33231 & .002 & 8.9642 & 24.0291 \\
\hline & \multirow{2}{*}{3} & 1 & $-27.88750^{*}$ & 3.12802 & .000 & -36.3461 & -19.4289 \\
\hline & & 2 & $-16.49667^{*}$ & 2.33231 & .002 & -24.0291 & -8.9642 \\
\hline
\end{tabular}

* The mean difference is significant at the 0.05 level.

Sources: calculated by the authors

the study period: in the Agricultural Blocks of the Ichhamati River Basin and the Coastal Saline Region, cropping intensity and irrigation intensity have both increased; and, in the Agricultural Blocks of the Gangetic Plain Region, cropping intensity has increased in spite of a decrease in irrigation intensity.

In North Twenty Four Parganas district, the gradual shrinkage of the net cropped area was observed due to the continuous conversion of agricultural land for non-agricultural use during the study period. Simultaneously, the rapid increase in population in this district brought the challenges of sustaining agricultural production and ensuring food security to the fore. In this context, enhancing cropping intensity in the district emerged as the priority. Therefore, it has been suggested that a comprehensive plan for water resource management, comprising the improvement of irrigation and the management of floods is required in the district. Particularly in the Coastal Saline Region, where both irrigation intensity and cropping intensity are low compared to the rest of the district, special attention is needed for the overall improvement of irrigation intensity and cropping intensity. In the Coastal Saline Region, rainwater harvesting needs to be promoted to improve the availability of irrigation water.

\section{Acknowledgement}

Authors would like to acknowledge the Department of Science \& Technology (DST), Government of India for providing financial assistance from DST PURSE Programme, University of Kalyani, West Bengal, India in carrying out this research.

\section{ORCID}

Tarun Kumar Mondal (1D https://orcid.org/0000-0002-8637-1958 Santana Sarkar (D) https://orcid.org/0000-0002-2038-8394

\section{References}

Bera, S \& Das Chatterjee, N 2019, 'Mapping and monitoring of land use dynamics with their change hotspot in North 24 Parganas district, India: a geospatial and statistical based approach', Modeling Earth Systems and Environments, vol 5, no. 4, pp.1529-1551.

Bezbaruah, MP \& Roy, N 2002, 'Factors affecting cropping intensity and use of fertilizers and high-yielding variety seeds in Barak Valley', Indian Journal of Agricultural Economics, Indian Society of Agricultural Economics, vol. 57, no. 2, pp.169-179.

Bhattarai, M, Sakthivadivel, R \& Hussain, I 2002, 'Irrigation impacts on income inequality and poverty alleviation: Policy issues and options for improved management of irrigation systems', Colombo International Water Management
Institute Working Paper, no. 39. Available from: <http:// www.iwmi.cgiar.org/Publications/Working_Papers/working/ WOR39.pdf>. [20 October 2019].

Biradar, CM \& Xiao, X 2011, 'Quantifying the area and spatial distribution of double - and triple-cropping croplands in India with multi temporal MODIS imagery in 2005', International Journal of Remote Sensing, vol. 32, no.2, pp.367-386.

Bureau of Applied Economics and Statistics (BAES), Department of Planning, Statistics and Programme Monitoring (DPSPM), Government of West Bengal (GoWB) 2015, Statistical Abstract West Bengal 2015, Kolkata. Available from: <http://www.wbpspm.gov. in/SiteFiles/Publications/10_18052017120546.pdf>. [30 September 2019]. 
Danda, AA, Sriskanthan, G, Ghosh, A, Bandyopadhyay, J, Ghosh, A \& Hazra, S 2011, Indian Sundarbans Delta: A vision, World Wide Fund for Nature-India, New Delhi.

Das, S \& Angadi, DP 2000, 'Land use-land cover (LULC) transformation and its relation with land surface temperature changes: A case study of Barrackpore Subdivision, West Bengal, India', Remote Sensing Applications: Society and Environment, vol. 19. Available from: <https://doi.org/10.1016/j.rsase.2020.100322>. [10 March 2021].

Datta, P, Sadhu, S, Bhattacharya, BN \& Majumdar, PK 2008, 'Demographic effects of forced illegal migration from Bangladesh to West Bengal: A qualitative study', Dialogue, vol. 10, no. 2. Available from: <http://www.asthabharati.org/ Dia_Oct\%2008/Pran.htm>. [21 June 2019].

Dayal, E 1978, 'A measurement of cropping intensity', Professional Geographer, vol.30, no. 3, pp.289-296.

Development and Planning Department (DPD), Government of West Bengal (GoWB) 2010, District Human Development Report: North 24 Parganas, 2010, West Bengal. Available from: <http://www.wbpspm.gov.in/SiteFiles/ Publications/13_19062017130648.PDF>. [20 May 2019].

Dhali, MK, Chakraborty, M \& Sahana, M 2019, 'Assessing spatiotemporal growth of urban sub-centre using Shannon's entropy model and principle component analysis: A case from North 24 Parganas, lower Ganga River Basin, India', Egyptian Journal of Remote Sensing Space Sciences, vol. 22, no. 1, pp.25-35.

Dhar, RB, Chakraborty, S, Chattopadhyay, R \& Sikdar, PK 2019, 'Impact of land-use/land-cover change on land surface temperature using satellite data: A case study of Rajarhat Block, North 24-Parganas District, West Bengal', Journal of the Indian Society of Remote Sensing, vol. 47, no. 2, pp. 331-348.

Dhawan, BD \& Datta, HS 1992 'Impact of irrigation on multiple cropping', Economic and Political Weekly, vol. 27, no.13, pp. A15-A18.

Dhawan, BD 1988, 'Indian irrigation: An assessment', Economic and Political Weekly, vol.23, no.19, pp. 965-971.

District Level Implementation Committee (DLIC), Pradhan Mantri Krishi Sinchayee Yojana (PMKSY) \& District Magistrate (DM), North 24 Parganas 2016, District Irrigation Plan (DIP) under Pradhan Mantri Krishi Sinchayee Yojana (PMKSY), North 24 Parganas 201617-2020-21, West Bengal. Available from: <https://pmksy. gov.in/mis/Uploads/2016/20161206011040799-1.pdf>. [15 September 2019].

District Management Section (DMS), North Twenty Four Parganas District, 2017, District Disaster Management Plan (2016-17), Disaster Management Section of the Office of the District Magistrate, North 24 Parganas District, Government of West Bengal.Available from: <http://wbdmd.gov.in/ writereaddata/uploaded/DP/North\%2024\%20parganas. pdf>. [25 January 2020].

Ghosh, S 2011, 'Cross-border activities in everyday life: the Bengal borderland', Contemporary South Asia, vol. 19, no. 1, pp.49-60.

Gillan, M 2002, 'Refugees or infiltrators? The Bharatiya Janata Party and "illegal" migration from Bangladesh', Asian Studies Review, vol. 26, no. 1, pp. 73-95.

Government of India (Gol) 1991, Census of India 1991, Office of the Registrar General \& Census Commissioner, Ministry of Home Affairs, India. Available from: <https://censusindia. gov.in>. [20 August 2020].
Government of India (Gol) 2001, Census of India 2001, Office of the Registrar General \& Census Commissioner, Ministry of Home Affairs, India. Available from: <https://censusindia. gov.in>. [20 August 2020].

Government of India (Gol) 2011, Census of India 2011, Office of the Registrar General \& Census Commissioner, Ministry of Home Affairs, India. Available from: <https://censusindia. gov.in>. [20 June 2019].

Guha, A 2000, Environment Induced Resettlement and Profit-Sharing Model: A case study from Sundarban, West Bengal. Available from: <https://doi.org/10.1016/j. envdev.2020.100523>. [12 February 2021].

Helsel, DR \& Hirsch, RM 2002, Statistical methods in water resources, techniques of water resources investigations, vol. 4, chapter A3, US Geological Survey, Reston, Virginia.

Hussain, I \& Hanjra, MA 2004, 'Irrigation and poverty alleviation: Review of the empirical evidence', Irrigation and Drainage, vol. 53, no.1, pp. 1-15.

Jain, M, Mondal, P, DeFries, RS, Small, C \& Galford, GL 2013, 'Mapping cropping intensity of smallholder farms: A comparison of methods using multiple sensors', Remote Sensing of Environment, vol. 134, pp. 210-223.

Jobson, JD 1992, Applied multivariate data analysis, volume II: Categorical and multivariate methods, Springer-Verlag, New York.

Kaini, S, Gardner, T \& Sharma, AK 2020, 'Assessment of socioeconomic factors impacting on the cropping intensity of an irrigation scheme in developing countries', Irrigation and Drainage, vol. 69, no.3, pp. 363-375.

Murtagh, F \& Legendre, P 2014, 'Ward's hierarchical agglomerative clustering method: Which algorithms implement ward's criterion?', Journal of Classification, vol.31, no.3, pp.274-295.

Narayanamoorthy, A, Alli, P \& Suresh, R 2015, 'Is the role of irrigation in agricultural output declining in India?: A districtwise study at six time points', Indian Journal of Agricultural Economics, vol.70, no. 3, pp. 333-349.

Oehl, F, Sieverding, E, Ineichen, K, Mader, P, Boller, T \& Wiemken, A 2003, 'Impact of land use intensity on the species diversity of arbuscular mycorrhizal fungi in agroecosystems of Central Europe', Applied and Environmental Microbiology, vol. 69 , no. 5, pp. 2816-2824.

Reddy, MV \& Reddy, NBK 1992, 'Changing pattern of irrigation in Andhra Pradesh' in Socio-Economic Dimensions of Agriculture, New Dimensions in Agricultural Geography, ed. N Mohammad, Concept Publishing Company, New Delhi, pp. 239-261.

Sánchez-Triana, E, Paul, T, Ortolano, L \& Ruitenebeek, J 2014, Building resilience for sustainable development of the Sundarbans: Strategy report, The International Bank for Reconstruction and Development/The World Bank, Washington DC. Available from: <https://openknowledge. worldbank.org/bitstream/handle/10986/20116/880610R EVISED00ns000Strategy0Report.pdf?sequence $=1>$. $\quad[5$ September 2019].

Sahana, M, Ahmed, R \& Sajjad, H 2016, 'Analyzing land surface temperature distribution in response to land use/land cover change using split window algorithm and spectral radiance model in Sundarban Biosphere Reserve, India', Modeling of Earth Systems Environment, vol. 2, no. 2, pp.1-11.

Sharma, VP 2015, 'Dynamics of land use competition in India: Perceptions and realities', Ahmedabad Indian Institute of Management Working Paper, no. 201506-02. Available from: <https://web.iima.ac.in/assets/ 
MISCELLANEA GEOGRAPHICA - REGIONAL STUDIES ON DEVELOPMENT

Vol. 25 • No. 4 • 2021 • pp. 246-258 • ISSN: 2084-6118 • DOI: 10.2478/mgrsd-2020-0063

snippets/workingpaperpdf/20799648232015-06-02.pdf>. [22 October 2019].

Siebert, S, Portmann, FT \& Döll, P 2010, 'Global patterns of cropland use intensity', Remote Sensing, vol. 2, no.7, pp. 1625-1643.

Ward, JH 1963, 'Hierarchical grouping to optimize an objective function', Journal of the American Statistical Association, vol. 58, no.301, pp. 236-244. 